\title{
Serological and Molecular Detection of Avian Influenza Virus Hemagglutinin (H5) in Wild Birds in and Around Zaria, Nigeria
}

\author{
${ }^{1}$ Alonge, P. I., ${ }^{1}$ Oladele, S. B., ${ }^{2}$ Hassan, F. B., ${ }^{1 *}$ Orakpoghenor, O. and ${ }^{1}$ Samuel, J.
}

\author{
${ }^{1}$ Department of Veterinary Pathology, Faculty of Veterinary Medicine, Ahmadu Bello University, Zaria, Nigeria \\ ${ }^{2}$ College of Agriculture and Animal Sciences, Mando, Kaduna Nigeria
}

*Author for Correspondence: ochuko.orakpoghenor@gmail.com

\begin{abstract}
Avian influenza (AI) has a worldwide distribution and affects domestic and wild birds, thus causing great economic losses to the poultry industry. This study was carried out to detect avian influenza virus H5 antibodies and nucleic acid in some wild birds [Laughing doves (Spilolepia senegalensis), Speckled pigeons (Columba guinea), Cattle egrets (Bubulcus ibis), Senegalese parrots (Poicephalus senegalus), Mallards (Anas platyrhynchos) and Geese (Anser anserini)] in Zaria and its environs, Kaduna State Nigeria. Sera were tested for avian influenza virus (AIV) H5 antibody using competitive enzyme linked immunosorbent assay (cELISA). Pooled oropharyngeal and cloacal swabs of each bird species (8-10 samples) were tested for AIV nucleic acid using one-step reverse transcriptase polymerase chain reaction (RT-PCR). Results revealed overall prevalence of $6.62 \%$ and $3.85 \%$ for AIV antibody and nucleic acid respectively. Based on species, AIV antibody was detected in laughing dove (10\%), speckled pigeon (13.64\%) and mallard (19.05\%). Also, AIV antigen was detected in Senegalese parrot (20\%). In conclusion, AIV antibody and antigen were detected in wild birds in Zaria, Nigeria. Thus, these species of birds could play significant roles in the spread of this virus to chickens. Therefore, measures to limit the interactions of these wild birds with chickens should be implemented to minimize the spread of AI.
\end{abstract}

Keywords: Avian influenza; Antibody; Antigen; Wild birds; Zaria

\section{INTRODUCTION}

Avian influenza (AI) is a highly contagious viral disease of domestic and wild birds with a worldwide distribution (Vincent et al., 2011; Ansari et al., 2016; Mohammed et al., 2017). The disease is caused by single stranded 8 -segmented negative sensed riboxynucleic acid (-ssRNA) viruses belonging to the genus Influenza A viruses in the family Orthomyxoviridae (Alexander, 2000; OIE, 2015). The natural reservoirs of influenza A viruses are avian species within the orders Anseriformes (waterfowl: ducks, swans, geese) and Charadriformes (gulls, terns and shorebirds) (Webster et al., 1992; Olsen et al., 2006). Influenza A viruses infect different species of mammals, including humans, pigs, marine mammals, and a wide range of birds, including both domestic and wild species (Abad et al., 2013). Generally, AI virus has been reported to be transmitted by the faecal-oral route without causing clinical signs in wild birds (Yu et al., 2008).

Avian influenza viruses (AIV) are divided into two groups: highly pathogenic avian influenza virus (HPAI) with $100 \%$ mortality rate and low pathogenic avian influenza virus (LPAI), often detected in wild birds (Rebel et al., 2011).
All highly virulent strains of AIV isolated from disease outbreaks have been either of the H5 or H7 subtype, though other subtypes have been detected with virulent characteristics (Wood et al., 1996).

The clinical signs of AI include haemorrhages distributed all over the body, oedema, cutaneous ischemia and cyanosis of comb and wattles, respiratory and neurological signs (Feldmann et al., 2000; Zanella et al., 2001; Bowes et al., 2004; Spackman et al., 2016; Pantin-Jackwood et al., 2017). However, the absence of clinical signs is common in LPAIV infection in chickens and ducks (Swayne et al., 2013). There are no pathognomonic lesions for avian influenza in birds (Stallknecht and Brown, 2007). Severity and distribution of lesions are dependent on the pathogenicity of the virus and host factors (e.g. species, age, immunity) (Stallknecht and Brown, 2007).

In Nigeria, the first outbreak of HPAI virus H5N1 strain was detected in a commercial poultry farm in Kaduna State, North Central Nigeria in 2006 (Joannis et al., 2006; De Benedictis et al., 2007). This involved different poultry species, mostly chickens of different ages, reared and bred on the same premises with some numbers of ducks, geese, turkeys and ostriches (Akanbi et al., 2016). Also, outbreak 
of HPAI subtype H5N8 has been reported in Jos, Plateau State in 9-week-old pullets and 4-week-old broilers (Ameji et al., 2019).

Influenza A viruses that reside naturally in wild bird species comprise all known subtypes and these provide viral genes for influenza viruses that infect both domestic poultry and mammalian species, including humans (Nguyen et al., 2005). Migratory birds and movement of poultry and/or poultry products have been proposed as two major mechanisms of geographic spread of avian influenza (Kilpatrick et al., 2006). Therefore, the aim of this study was to detect AIV antibody and antigen in some wild birds in Zaria and its environs, Nigeria.

\section{MATERIALS AND METHODS}

\section{Study Area and Birds Sampled}

This study was carried out in Sabon-Gari and Samaru, Zaria, Nigeria. The species of birds used for the study were laughing doves (Spilolepia senegalensis) (LD), speckled pigeons (Columba guinea) (SP), cattle egrets (Bubulcus ibis) (CE), Senegalese parrots (Poicephalus senegalus) (SPR), mallards (Anas platyrhynchos) and geese (Anser anserini). Some of the birds were captured alive around poultry houses using wooden traps, while some were purchased from live bird markets (LBMs). The birds were identified by an ornithologist and physical examination was conducted on each bird to be sure there were no lesions, external wounds or ectoparasites.

\section{Sample Collection}

Sampling of birds was purposive sampling technique based on availability of birds at the time of capture and purchase. A total of 136 birds, comprising 20 laughing doves, 22 speckled pigeons, 25 cattle egrets, 25 Senegalese parrots, 21 mallards and 23 geese were sampled over a period of 9 months (April-to-December 2018).

Blood sample was collected from each bird via the wing vein using sterile syringes and $23 \mathrm{G}$ hypodermic needles, dispensed into labelled plain Vacutainer tubes and allowed to clot at room temperature. Thereafter, the formed serum was transferred into labelled cryotubes and stored at $-20^{\circ} \mathrm{C}$ until used for detection of AIV antibodies.

Oropharyngeal and cloacal swabs from each bird were collected using Dacron swab (Huachenyang Technology Co. Ltd, China), dispersed in labelled sample bottle containing about $1 \mathrm{ml}$ of virus transport medium (VTM) (National Veterinary Research Institute, Vom, Nigeria) and pooled together. Pooled swabs of about 4-5 birds of the same species were further pooled together to increase the concentration of antigen for possible detection. The total numbers of pooled oropharyngeal and cloacal swabs for laughing dove, speckled pigeon, Senegalese parrot, cattle egret, mallards and geese were $4,4,5,5,4$ and 4, respectively. The swab and VTM were thoroughly mixed and the mixture of swab content and VTM was stored at $20^{\circ} \mathrm{C}$ until used for viral molecular detection.

\section{Enzyme Linked Immunosorbent Assay for Detection of Avian Influenza Virus H5 Antibody}

This assay was carried out in the Virus Research Division Laboratory of the National Veterinary Research Institute (NVRI), Vom, Jos, Plateau State using avian influenza virus antibody test kit (ID.vet Innovative Diagnostics, 310, rue Louis Pasteur - Grabels - France). Test serum samples were subjected to competitive ELISA following the manufacturers' instructions (ID Screen Influenza H5 antibody competition protocol). The optical density (OD) values were measured and recorded at $450 \mathrm{~nm}$ wavelength using ELISA microtitre plate reader (Thermo Scientific, Multiskan Ex). Competition percentage (S/N\%) of each sample was calculated as shown below:

$\mathrm{S} / \mathrm{N} \%=\frac{\text { Optical density of sample }}{\text { Optical density of negative control }} \times 100$

Serum samples with $\mathrm{S} / \mathrm{N} \%>50$ were considered negative while serum samples with $\mathrm{S} / \mathrm{N} \% \leq 50$ were considered positive for AIV antibodies according to the manufacturers' instructions.

\section{Reverse Transcription Polymerase Chain Reaction to Detect Avian Influenza Virus H5 Nucleic Acid}

One-step reverse transcription polymerase chain reaction (RT-PCR) was performed in the Avian Influenza Research Laboratory, NVRI, Vom, Plateau State. It was performed using QIAGEN RT-PCR kit targeting the matrix (M) gene in a 9700 thermocycler (Life Technologies, Foster City, CA, USA) as originally described by Spackman et al. (2002). The following modified primers (H5LH1: 5' ACG TAT GAC TAT CCA CAA TAC TCA G 3'; H5RH1: 5' AGA CCA GCT ACC ATG ATT GC 3') were used. The following thermal profile was used: a single cycle of reverse transcription for $30 \mathrm{~min}$ at $50^{\circ} \mathrm{C}, 2 \mathrm{~min}$ at $95^{\circ} \mathrm{C}$ for reverse transcriptase inactivation and DNA polymerase activation followed by 40 amplification cycles of $15 \mathrm{sec}$ at $95^{\circ} \mathrm{C}$ and 1 min at $60^{\circ} \mathrm{C}$ (annealing-extension step). The amplified PCR products were then visualized on $1.5 \%$ agarose gel stained with ethidium bromide.

\section{Ethical Statement}

The use of animals in this study was approved by the Ahmadu Bello University Zaria Committee on Animal Use and Care (ABUCAUC) with number ABUCAUC/2017/080

\section{Data Analyses}

The ELISA and RT-PCR data were presented as percentages in tables. The prevalence of AIV antibody and antigen for each bird species was calculated using the formula outlined by Bennette et al. (1991):

Prevalence for each species $(\%)=$

Number of serum positive for each species $\mathrm{x} 100$

Total number of serum examined for the species

The RT-PCR results were reported as positive or negative detection. 


\section{RESULTS}

An overall AIV H5 seroprevalence rate of $6.62 \%$ was observed amongst the different classes of wild birds studied in Zaria and environs, Nigeria using cELISA. The distribution of the positive samples showed 2/ 20 (10\%) of laughing dove, $3 / 22(13.64 \%)$ of speckled pigeon and $4 / 21$ $(19.05 \%)$ of mallard sera were positive for AIV H5 antibodies (Table 1). All the remaining birds tested negative for AIV H5 antibodies using cELISA (Table 1). Out of all the pooled oropharyngeal and cloacal swabs from the different classes of birds, only 1/20 (20\%) Senegalese parrot swab sample was positive for AIV H5 nucleic acid using RT-PCR, giving an overall detection rate of $3.85 \%$ (Table 2 ). All the remaining pooled samples from the other classes of birds tested negative for AIV H5 nucleic acid using RTPCR (Table 2).

Table 1: Distribution of avian influenza virus $\mathrm{H} 5$ antibodies in some wild birds in Zaria and environs, Kaduna State Nigeria using competitive enzyme linked immunosorbent assay.

\begin{tabular}{lcc}
\hline $\begin{array}{l}\text { Species } \\
\text { of Bird }\end{array}$ & $\begin{array}{l}\text { Number of Sera } \\
\text { Tested }\end{array}$ & Number (\%) Positive \\
\hline Laughing dove & 20 & $2(10.00)$ \\
Speckled pigeon & 22 & $3(13.64)$ \\
Senegalese parrot & 25 & $0(0.00)$ \\
Cattle egret & 25 & $0(0.00)$ \\
Mallard & 21 & $4(19.05)$ \\
Geese & 23 & $0(0.00)$ \\
\hline Total & $\mathbf{1 3 6}$ & $\mathbf{9 ( 6 . 6 2 )}$ \\
\hline
\end{tabular}

Table 2: Distribution of avian influenza virus nucleic acid in some wild birds in Zaria and environs, Kaduna State Nigeria, using reverse transcriptase polymerase chain reaction

\begin{tabular}{lcc}
\hline $\begin{array}{l}\text { Species } \\
\text { of Bird }\end{array}$ & $\begin{array}{l}\text { Number of Pooled } \\
\text { Oropharyngeal and Cloacal } \\
\text { Swabs Tested }\end{array}$ & $\begin{array}{l}\text { Number (\%) Positive Pooled } \\
\text { Swabs }\end{array}$ \\
\hline Laughing dove & 4 & $0(0.00)$ \\
Speckled pigeon & 4 & $0(0.00)$ \\
Senegalese parrot & 5 & $1(20.00)$ \\
Cattle egret & 5 & $0(0.00)$ \\
Mallard & 4 & $0(0.00)$ \\
Geese & 4 & $0(0.00)$ \\
\hline Total & $\mathbf{2 6}$ & $\mathbf{1 ( 3 . 8 5 )}$ \\
\hline
\end{tabular}

\section{DISCUSSION}

This study has confirmed the presence of AIV H5 antibody and antigen in some wild birds in Zaria and its environs. The overall prevalence $(6.62 \%)$ recorded for AIV H5 antibody is higher than $4.5 \%$ reported in Kogi State, Nigeria (Ameji et al., 2017) and $0.8 \%$ in Uganda (Kirunda et al., 2014); but similar to the $6.8 \%$ in Egypt (Ahmed et al., 2017). The species distribution showed that laughing doves $(10 \%)$, speckled pigeons (13.64 \%) and mallards $(19.05 \%)$ were positive for AIV H5 antibody. Although wild aquatic birds, particularly waterfowls, have been reported to be the natural hosts for influenza A viruses (Olsen et al., 2006), these species of birds are not strictly aquatic birds, yet had antibodies against AIV. This implies that non-aquatic birds could play roles in the spread of AIV. Thus, avian influenza represents one of the greatest concerns to the poultry industry and public health (Capua and Marangon, 2006).

The AIV seroprevalence rates of $19.05 \%$ observed in this study, is higher than $2.7 \%$ reported by Kirunda et al. (2014) in Uganda. The AIV seroprevalence in mallards is suggestive of previous exposure to the virus, resulting from possible interaction with other infected birds.

The AIV seroprevalences in laughing doves (10\%) and speckled pigeons $(13.64 \%)$ recorded in this study does not agree with the $0 \%$ seroprevalence rate reported among laughing doves and speckled pigeons in some states of Nigeria by Adamu et al. (2017), Musa et al. (2017) and Ameji et al. (2017). This suggests that the laughing doves and speckled pigeons in this study might have been previously exposed to AIV through possible interaction with other species of wild birds that were infected with the virus.

Senegalese parrots, geese and cattle egrets were seronegative for AIV H5 in this study. Musa et al. (2017) reported similar observation in Nigeria amongst Senegalese parrots and geese, but with $23.5 \%$ AIV seroprevalence rate in cattle egrets. However, AIV antigen was detected in $20 \%$ of only the Senegalese parrot tested, but not in the other classes of birds tested. This is lower than the $8 \%$ reported by Adamu et al. (2017) among speckled pigeons in Kano Nigeria. The higher AIV nucleic acid detection rate observed in this study might be due to the increased sensitivity of the detection test (RT-PCR). Hence, the use of 
PCR allows for rapid identification of AI in clinical specimens, faster decision making at the early stages of an outbreak and implementation of effective control measures. Senegalese parrots were negative for AIV H5 antibody but positive for AIV H5 antigens using RT-PCR. This therefore, suggests a possible active infection resulting from interaction in the bush and wetland with other species of wild birds that were likely infected with the virus (Adamu et al., 2017). The absence of AIV H5 antigen in seropositive birds is suggestive of possible virus clearance.

\section{Conclusion}

Avian influenza virus antibody $(6.62 \%)$ and antigen $(3.85$ $\%$ ) were detected in some wild birds in Zaria and its environs. These birds therefore could play significant roles in the natural spread of AI. Therefore, interaction between these species of wild birds and domestic poultry should be limited to minimize spread of AI. Also, further studies on the isolation and characterization of avian influenza virus from wild birds should be carried out.

\section{Acknowledgements}

We acknowledge the technical staff of the Department of Veterinary Public Health and Preventive Medicine, Ahmadu Bello University, Zaria, Kaduna State, Nigeria; National Veterinary Research Institute Vom, Plateau State Nigeria.

\section{Conflict of Interest}

The authors have no conflict of interest to declare.

\section{Authors Contributions}

PIA, OO and JS performed the experiment. SBO and FBH supervised the research. OO drafted the manuscript. All authors have read and approved the final manuscript.

\section{References}

Abad, F. X., Busquets, N., Sanchez, A., Ryan, P. G., Majo, N. and Gonzalez-Solis, J. (2013). Serological and virological surveys of the influenza A viruses in Antarctic and sub-Antarctic penguins. Antarctic Science, 25(2): 339-344.

Adamu, H. U., Balami, A. G. and Abdu, P. A. (2017). Avian influenza, Gumboro and Newcastle disease antibodies and antigens in apparently healthy wild birds in Kano metropolis, Nigeria. Nigeria Vet. J., 38(1): 69-77.

Ahmed, B. M., El-Shazly, M. M., El-Sanousi, A. A. and Youssef, Y. I. (2017). Isolation of H5 highly pathogenic avian influenza virus from Cattle egret (Bubulcus ibis) near affected broiler chicken flocks in Egypt. J. Virological Science, 2: 62-70.

Akanbi, O. B., Ekong, P. S., Odita, C. I. and Taiwo, V. O. (2016). The effect of highly pathogenic avian influenza (HPAI) H5N1 outbreaks on mixed species poultry farms in Nigeria. J. World Poultry Res., 6(3): 147-152.

Alexander, D. J. (2000). A review of avian influenza in different bird species. Vet. Microbiol., 74(1-2): 313.
Ameji, N. O., Sa'idu, L. and Abdu, P. A. (2017). Detection of avian influenza antibodies and antigens in poultry and some wild birds in Kogi State, Nigeria. Sokoto J. Vet. Sciences, 15(3): 62-68.

Ansari, W. K., Parvej, M. S., El-Zowalaty, M. E., Jackson, S., Bustin, S. A., et al., (2016). Surveillance, epidemiological and virological detection of highly pathogenic $\mathrm{H} 5 \mathrm{~N} 1$ avian influenza viruses in duck and poultry from Bangladesh. Vet. Microbiol., 193: 49-59.

Bennette, S., Woods, T., Liyanage, W. M. and Smith, D. L. (1991). A simplified general method for cluster sampling surveys of health in developing countries. World Health Statistician Quarterly, 44: 98-106.

Bowes, V. A., Ritchie, S. J., Byrne, S., Sojonky, K., Bidulka, J. J. and Robinson, J. H. (2004). Virus characterization, clinical presentation, and pathology associated with $\mathrm{H} 7 \mathrm{~N} 3$ avian influenza in British Columbia broiler breeder chickens in 2004. Avian Dis., 48(4): 928-934.

Capua, I. and Marangon, S. (2006). Control of avian influenza in poultry. Emerg. Infectious Dis., 12(9): 1319-1324.

De Benedictis, P., Joannis, T., Lombin, L. H., Shittu, I., Beato, M. S., et al., (2007). Field and laboratory findings of the first incursion of the Asian H5N1 highly pathogenic avian influenza virus in Africa. Avian Pathol., 36: 115-117.

Fagbohun, O. A., Owoade, A. A., Oluwayelu, D. O. and Olayemi, F. O. (2000). Serological survey of infectious bursal disease virus antibodies in Cattle egrets, pigeons and Nigerian laughing doves. African J. Biomed. Res., 3(3): 191-192.

Feldmann, A., Schafer, M. K. H., Garten, W. and Klenk, H. (2000). Targeted infection of endothelial cells by avian influenza virus A/FPV/Rostock/34 (H7N1) in chicken embryos. J. Virol., 74(17): 8018-8027.

Joannis, T., Lombin, L. H., De Benedictis, P., Cattoli, G. and Capua, I. (2006). Confirmation of H5N1 avian influenza in Africa. The Vet. Rec., 158: 309-310.

Kilpatrick, A. M., Chmura, A. A., Gibbons, D. W., Fleischer, R. C., Marra, P. P. and Daszak, P. (2006). Predicting the global spread of H5N1 avian influenza. Proceedings of the National Academy of Science, 103: 19368-19373.

Kirunda, H., Erima, B., Tumushabe, A., Kiconco, J., Tugume, T., et al., (2014). Prevalence of influenza A viruses in livestock and free-living waterfowl in Uganda. Biomed Central Vet. Res., 10(50): 1-9.

Mohammed, Y. Z., Abdul-Dahiru, E., Yasheruram, M. S., Meshach, M. M., Mustapha, B. A., et al., (2017). Serological detection of avian influenza virus (H5N2) antibody among domestic avian species in Maiduguri Metropolis, Nigeria. Int. J. Advance Agric. Res., 5: 23-33.

Musa, W. I., Abdullahi, B. Y., Lawal, S., Bello, M. and Abdu, P. A. (2017). Detection of antibodies to avian influenza, infectious bronchitis and Newcastle disease viruses in wild birds in three states of Nigeria. Sokoto J. Vet. Sciencs, 15: 28-35. 
Nguyen, D. C., Uyeki, T. M., Jadhao, S., Maines, T., Shaw, M., et al., (2005). Isolation and characterization of avian influenza viruses, including highly pathogenic $\mathrm{H} 5 \mathrm{~N} 1$, from poultry in live bird markets inHanoi, Vietnam, in 2001. J. Virol., 79(7): 4201-4212.

OIE. (2015). Avian influenza. In: Manual of Diagnostic Tests and Vaccines for Terrestrial Animals. 5th ed. Office International des Epizooties, Paris, France. pp. 270-282.

Olsen, B., Munster, V. J., Wallensten, A., Waldenström, J., Osterhaus, A. D. and Fouchier, R. A. (2006). Global patterns of influenza A virus in wild birds. Science, 312: 384-388.

Pantin-Jackwood, M. J., Stephens, C. B., Bertran, K., Swayne, D. E. and Spackman, E. (2017). The pathogenesis of H7N8 low and highly pathogenic avian influenza viruses from the United States 2016 outbreak in chickens, turkeys and mallards. PLoS ONE, 12(5): 1-21.

Rebel, J. M., Peeters, M., Fijten, H., Post, J., Cornelissen, J. and Vervelde, L. (2011). Highly pathogenic or low pathogenic avian influenza virus subtype $\mathrm{H} 7 \mathrm{~N} 1$ infection in chicken lungs: Small differences in general acute responses. Vet. Res., 42: 10-16.

Spackman, E., Pantin-Jackwood, M. J., Kapczynski, D. R., Swayne, D. E. and Suarez, D. L. (2016). H5N2 highly pathogenic avian influenza viruses from the US 2014-2015out break have an unusually long pre-clinical period in turkeys. BMC Vet. Res., 12(1): 260 .

Spackman, E., Senne, D. A., Myers, T. J., Bulaga, L. L., Garber, L. P., et al., (2002). Development of a real- time reverse transcriptase PCR assay for type A influenza virus and the avian $\mathrm{H} 5$ and $\mathrm{H} 7$ haemagglutinin subtypes. J. Clin. Microbiol., 40: 3256-3260.

Stallknecht, D. E. and Brown, J. D. (2007). Wild birds and the epidemiology of avian influenza. J. Wildl. Dis., 43: S15-S20.

Swayne, D. E., Suarez, D. L. and Sims, L. D. (2013). Influenza. In: Swayne D (ed). Diseases of Poultry. $13^{\text {th }}$ ed. Blackwell Publisher, Ames, IA, Pp. 181218.

Vincent, M., Xiaoyan, Z., Edith, M., Beibei, J., Guo, F., et al., (2011). Risk-based surveillance for avian influenza control along poultry market chains in South China: The value of social network analysis. doi:10.1016/j.prevetmed.2011.07.007

Webster, R. G., Bean, W. J., Gorman, O. T., Chambers, T. M. and Kawaoka, Y. (1992). Evolution and ecology of influenza A viruses. Microbiol. Rev., 56(1): 152-179.

Wood, G. W., Banks, J., Strong, I., Parsons, G. and Alexander, D. J. (1996). An avian influenza virus of H10 subtype that is highly pathogenic for chickens but lacks multiple basic amino acids at the haemagglutinin cleavage site. Avian Pathol., 25: 799-806.

Yu, Y., Kikuyasu, N., Masatoshi, O., Manabu, Y. and Masaji, M. (2008). Avian influenza virus (H5N1) replication in feathers of domestic waterfowl. Emerg. Infectious Dis., 14(1): 1-9.

Zanella, A., Dall'Ara, P. and Martino, P. A. (2001). Avian influenza epidemic in Italy due to serovar H7N1. Avian Dis., $\quad 45(1)$ : 257-261. 